\title{
Performance management as a mediator for work engagement and employment relationships in the public sector in South Africa
}

\begin{tabular}{|c|c|}
\hline \multicolumn{2}{|c|}{$\begin{array}{l}\text { Authors: } \\
\text { Godfrey Maake }{ }^{1} \\
\text { Cornelia P. Harmse } \\
\text { Cecilia M. Schultz }\end{array}$} \\
\hline $\begin{array}{l}\text { Affiliations: } \\
{ }^{1} \text { Department o } \\
\text { Information M } \\
\text { Services, Facul } \\
\text { Management } \\
\text { Tshwane Unive } \\
\text { Technology, Ts! } \\
\text { South Africa }\end{array}$ & $\begin{array}{l}\text { Business and } \\
\text { nagement } \\
\text { y of } \\
\text { ciences, } \\
\text { sity of } \\
\text { wane, }\end{array}$ \\
\hline $\begin{array}{l}{ }^{2} \text { Department o } \\
\text { Management } \\
\text { Development, } \\
\text { Management } \\
\text { Tshwane Unive } \\
\text { Technology, Ts } \\
\text { South Africa }\end{array}$ & $\begin{array}{l}\text { People } \\
\text { nd } \\
\text { aculty of } \\
\text { ciences, } \\
\text { sity of } \\
\text { wane, }\end{array}$ \\
\hline $\begin{array}{l}\text { Corresponding } \\
\text { Godfrey Maake } \\
\text { maakeig@yahc }\end{array}$ & $\begin{array}{l}\text { author: } \\
\text { o.com }\end{array}$ \\
\hline $\begin{array}{l}\text { Dates: } \\
\text { Received: } 02 \mathrm{~N} \\
\text { Accepted: } 24 \mathrm{~A} \\
\text { Published: } 09 \mathrm{~N}\end{array}$ & $\begin{array}{l}\text { v. } 2020 \\
\text { ug. } 2020 \\
\text { ov. } 2021\end{array}$ \\
\hline $\begin{array}{l}\text { How to cite th } \\
\text { Maake, G., Har } \\
\text { Schultz, C.M. (2 } \\
\text { Performance m } \\
\text { mediator for w } \\
\text { and employme } \\
\text { in the public se } \\
\text { Africa. SA Journ } \\
\text { Resource Manc } \\
\text { Tydskrif vir } \\
\text { Menslikehulpbr } \\
\text { 19(0), a1507. h } \\
\text { org/10.4102/sa } \\
\text { v19i0.1507 }\end{array}$ & $\begin{array}{l}\text { article: } \\
\text { se, C.P., \& } \\
21 \text { ). } \\
\text { anagement as a } \\
\text { rk engagement } \\
\text { tt relationships } \\
\text { tor in South } \\
\text { al of Human } \\
\text { gement/SA } \\
\text { nhestuur, } \\
\text { tps://doi. } \\
\text { hrm. }\end{array}$ \\
\hline $\begin{array}{l}\text { Copyright: } \\
\text { (C) 2021. The A } \\
\text { Licensee: AOSI } \\
\text { is licensed und } \\
\text { Creative Comm } \\
\text { License. }\end{array}$ & $\begin{array}{l}\text { thors. } \\
\text { This work } \\
\text { on the } \\
\text { ons Attribution }\end{array}$ \\
\hline Read online: & \\
\hline 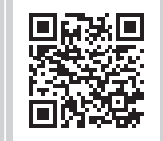 & $\begin{array}{l}\text { Scan this QR } \\
\text { code with your } \\
\text { smart phone or } \\
\text { mobile device } \\
\text { to read online. }\end{array}$ \\
\hline
\end{tabular}

Orientation: To improve service delivery to its citizens, the South African public sector should aim to improve employees' performance by implementing effective performance management that would impact positively on work engagement and employment relationships.

Research purpose: The primary objective of this study was to determine whether performance management could be a mediator for work engagement and employment relationships in the public sector in South Africa.

Motivation for the study: The success of the public sector relies primarily on performance management that strengthens work engagement and employment relationships, which in turn positively influence employee performance. Managers need to understand the influence of performance management on work engagement and employment relationships.

Research approach/design and method: A quantitative approach was employed. Nonprobability purposive sampling was used to select 400 permanent employees with more than 5 years of experience at job levels 1-12 in eight national departments based in Gauteng. A structured questionnaire was utilised as a data collection method in this study. The questionnaire for the study was divided into four sections and consisted of 74 Likert-scale questions.

Main findings: This study showed a moderate correlation between performance management and work engagement and a strong correlation between performance management and employment relationships. This study indicated that performance management was indeed a mediator between work engagement and employment relationships.

Practical/managerial implications: Management should ensure that employees understand the function of performance management as a whole, display a positive attitude towards the implementation of performance management, ensure that employees' Key Performance Indicator (KPIs) adequately reflect their areas of responsibility, motivate the use of performance management through the reward structure and finally, training and orientation on performance management should also be provided to newly appointed and existing staff members to ensure strong work engagement and good employment relationships.

Contribution/value-add: Contribution of the study to knowledge and practice surrounding performance management, work engagement and employment relationships. The contribution of this study is to impress on managers and leaders the influence of performance management on work engagement and employment relationships.

Keywords: performance; service delivery; management system; transparent; unbiased.

\section{Introduction}

The South African public sector is frequently criticised for not rendering quality services to the citizens of the country. Mafini and Pooe (2014) highlight the many challenges associated with underperformance in the South African public sector, and in 2016, the National Treasury admitted that the service delivery provided by South African government departments was below par (National Treasury, 2016). At the same time, the demand for improved service delivery remains high. West and Blackman (2015) argued that improvements are required from all government departments. These improvements may be achieved in part by ensuring that the performance of employees at all levels of the organisation is aligned with organisational objectives, which requires the effective implementation of performance management. 
According to Tweedie, Wild, Rhodes and Martinov-Bennie (2019), performance management is generally used by an organisation to assess and monitor employees' work. There is increasing awareness that performance management can help to change employee behaviour by fostering an intolerance for failure through cultivating transparency in the transfer of information and by ensuring efficient vertical and horizontal cooperation (Woyessa, 2015). Performance management has been the subject of much research, primarily because employees are regarded as the most critical element in any system, as it is their behaviour that ultimately determines the level of achievement of organisational objectives (West \& Blackman, 2015). Maimela and Samuel (2016) reported that performance management can have a huge influence on altering employee principles, attitudes and behaviour, and that this can, in turn, influence the culture of the organisation. Mbonambi (2016) suggested that making performance management part of the daily conversation can lead to better outcomes and performance throughout the organisation.

Public sector employees have experienced ineffectual performance management (Makamu, 2016). This has been found to have a negative influence on their levels of work engagement and on employment relationships. This can have an adverse influence on their performance, and for this reason, it is vital to foster effective performance through the implementation of effective performance management. In the South African public sector, performance management was introduced in July 1999 after the signing of Resolution 13 of 1998 and first became operational in April 2001. From that time, the government has constantly sought ways to maintain effective performance management that will address the challenges associated with the post-apartheid era (Isaacs, 2016).

Work engagement is a serious challenge. Gallup (2017) found that $85 \%$ of the employees globally are energetically disengaged in their work. Work engagement is a pillar of any successful business. Schaufeli, Salanova, Gonzalez-Roma and Bakker (2002) defined work engagement as an optimistic workassociated state of mind, usually categorised by vigour, dedication and absorption. Essentially, work engagement is an umbrella covering various outcomes in work as well as other variables that will support the organisation to achieve its goals (Rachman \& Suhartini, 2019). The findings indicate that three elements of work engagement, namely vigour, dedication and absorption, contribute towards the mental experience of employees that connects environmental and personal resources and performance (Kim, Han, \& Park, 2019). This could mean that a high level of work engagement in the organisation could assist employees to do their work more efficiently and effectively. In contrast, Rana, Pant and Chopra (2019) found that aspects of work engagement were predictors of employee performance and that work engagement had a significant impact on employee performance. Given the clear connection between work engagement and employees' work performance, Osborne and Hammoud (2017) believe that employees' engagement levels arise from their ability to control personal behaviours and goals. Based on a review of the literature, sustaining and enhancing high levels of work engagement not only lead to employee improved performance but also enhance business performance and improve the organisation's competitive advantage (Rana et al., 2019).

Al-Khozondar (2015) maintained that a solid employment relationship between employees and employers leads to higher levels of efficiency, motivation and performance. Furthermore, sound employment relationships between employers and employees are key to an organisation's success (Subramanian, 2017). Positive employment relationships generate a favourable working environment, which satisfies the needs of individual employees and managers in an organisation (Brhane \& Zewdie, 2018). Therefore, it is important for managers to create and maintain healthy relationships with their employees (Samwel, 2018).

Although several studies have been conducted on performance management, employment relationships and work engagement, limited literature exists on whether there is a relationship between these three aspects, especially within the public sector in South Africa. This study sought to determine the relationship between performance management, engagement and employment relationships and further to determine whether performance management is a mediator for work engagement and employment relationships in the public sector in South Africa. The study was deemed important in understanding that work engagement and employment relationships influence the performance of public sector employees.

\section{Research purpose and objectives}

Limited literature exists on the relationship between performance management, employment relationships and work engagement, specifically within the public sector in the South African environment. To gain deeper insight into whether performance management can influence employment relationships and work engagement, the following objectives were formulated:

- To determine whether there are any significant relationships amongst the three variables (performance management, work engagement and employment relationships) in the public sector in South Africa.

- To determine whether performance management is a mediator for work engagement and employment relationships.

\section{Literature review Performance management}

Performance management can be described as a process that helps an organisation to set goals (Okwir, Nudurupati, Ginieis, \& Angelis, 2018). Performance management is a general strategy that an organisation uses to assess and manage employees' work (Tweedie et al., 2019). The use of performance management can bring about controlled uncertainty, which enables the organisation to adapt to change to ensure survival 
(Okwir et al., 2018). Performance management is considered to be an influential instrument in disseminating an organisation's vision, mission and objectives from management to all employees (Mulwa \& Weru, 2017). According to Munzhedzi (2017), performance management can be seen as a guiding principle on how everything is to be completed, starting from goal setting and deciding how to measure accomplishments to providing consistent assessments. Performance management provides a systematic assessment tool that managers can use to make meaningful business decisions regarding rewards distribution, retention of high performers and consequences for poor performers (Gulch, 2016). Sachane, Bezuidenhout and Botha (2018) argued that performance management is a continual process that comprises formal practices, processes and systems, as well as informal activities and procedures.

According to Woyessa (2015, p. 25), one of the purposes of performance management is 'to define, measure and stimulate employee performance with the goal to improve the performance of an organisation'. Employees with common goals are more devoted to the organisation and rate their jobs and the organisation at a higher level (Matjila, 2015). Essentially, if managers and employees are not mindful of strategic objectives, it is improbable that performance management will help them to realise the strategic goals of the organisation (Mbonambi, 2016). Mbonambi (2016) further indicated that employees will improve their performance if they are aware of the organisational expectations if they know how to do the work and if they know the standard of work that is required.

Kotola (2016) asserted that performance management is a human resource management mechanism that builds the kind of workplace in which employees are empowered to execute their tasks as well as they possibly can. Gulch (2016) supported this idea, adding that performance management is a component under the human resource umbrella that plays a major role in contributing towards organisational performance. As noted by Nxumalo, Goudge, Gilson and Eyles (2018), the main aim of performance management is to provide employees with the status of their work performance and pinpoint their weaknesses and strengths. Nxumalo et al. (2018) go on to say that this process will assist the management of the organisation to determine employees who qualify for salary increments and promotions, recognise training and development needs, place employees based on their ability and provide possible reasons for any disciplinary measures.

\section{Work engagement}

Work engagement is an important element of organisational behaviour. One reason that work engagement is such an ongoing issue is that it is essentially a reliable forecaster of employee, team and organisational outcomes (Bakker \& Albrecht, 2018).

Kahn (1990) used the term 'engagement' to explicitly define a worker's level of immersion in given tasks. He posited that an individual's emotional and psychological state, though internal, is largely externally driven. This implies that the psychological state precipitating work engagement is significantly influenced by forces within the individual person's work environment (Rotich, Cheruiyot, \& Korir, 2016). According to Schaufeli et al. (2002), work engagement is characterised by vigour, dedication and absorption with regard to assigned tasks. Bakker (2017) agreed with the above-mentioned definitions by referring to work engagement as a positive, rewarding work-related mental state that is characterised by vigour (a high level of physical and cognitive energy), dedication and absorption (a clear focus and concentration on the work at hand). Pandita and Singhal (2017) argued that most people understand engagement as an attitude or behaviour that implies being busy with, involved in, attracted by, committed to, retained in and maintained in one's work or organisation.

If employees are engaged in their work, this can increase levels of well-being and work performance (Knight, Patterson, \& Dawson, 2017). Moreover, work engagement leads to higher job satisfaction; better performance, including an enhanced demonstration of personal ideas; lower absenteeism and turnover rates; improved health and safety; hands-on behaviour and motivation to learn. At its core, work engagement is viewed as:

[A] psychological, dynamic and dialectical relationship, the simultaneous employment and expression of a person's preferred self in task behaviours that promote connections to work, personal presence (physical, cognitive and emotional) and active full performances. (Kahn, 1990, p. 700)

Work engagement consists of three major elements, which are discussed in the following sections.

\section{Vigour}

Vigour is characterised by high levels of energy, resilience, willingness to invest effort, persistence in the face of problems and willingness to invest effort in one's work (De Spiegelaere, Van Gyes, \& Van Hootegem, 2016; Schaufeli et al., 2002). It is essential to note that employees who have high scores for vigour usually have a great deal of energy, enthusiasm and strength when working, whereas those who have low scores for vigour have less energy, enthusiasm and resilience as far as their work is concerned (Boikanyo \& Heyns, 2019).

\section{Dedication}

Dedication is characterised by employees' enthusiasm and pride about their work, a feeling of inspiration and a sense of meaning related to work (De Oliveira \& Rocha, 2017; De Spiegelaere et al., 2016). Dedication further refers to being highly involved in one's work and feeling a sense of importance, pride, worth, challenge, inspiration and enthusiasm from engaging with it (Patrick \& Mukherjee, 2018; Schaufeli et al., 2002; Van Wingerden, Bakker, \& Derks, 2016). The literature shows that employees with high scores for dedication intensely identify with their work because they experience it as meaningful, inspiring and challenging (Boikanyo \& Heyns, 2019). 


\section{Absorption}

Absorption is characterised by being totally focused and happily captivated with one's work to the extent that time passes rapidly and one finds it hard to disengage oneself from one's work (Boikanyo \& Heyns, 2019; Schaufeli et al., 2002; Van Wingerden et al., 2016). It is described as a mind-set in which one is extremely focused on and enchanted by one's work (De Spiegelaere et al., 2016).

The next aspect of the literature review aims to provide a better understanding of employment relationships.

\section{Employment relationships}

When managers and subordinates experience high-quality relationships, it leads to more constructive practices at work and the intention to stay with the organisation (Matthews, Carsten, Ayers, \& Menachemi, 2017). For any organisation to grow and prosper, an assessment of employment relationships is essential because of the influence that employee performance has on the organisation's efficiency (Hassan \& Hatmaker, 2016). The quantity and quality of work produced in an organisation are both positively and negatively affected by the relationships between employers and employees (Mundia et al., 2017). A strong relationship between manager and employee is vital in ensuring that organisational goals are achieved (Georgalis, Samaratunge, \& Kimberley, 2015).

Some, but by no means all, management components of employment relationships are described in more detail in the following subsections.

\section{Level of trust}

Rahman and Taniya (2017) emphasised that trust is considered to be one of the most prominent variables influencing organisational performance. Trust can grow, diminish or even become apparent because of a relationship. Research has shown that many South African supervisors do not value, respect or foster trust and do not display compliance, fairness and good faith in their dealings with subordinates (Ehlers, 2017).

\section{Compliance}

Xesha, Iwu, Slabbert and Nduna (2014) posited that to build strong relationships in an organisation, managers must ensure that they comply with labour laws or face penalties and the end of the relationship they have with the employees. It should also be noted that employment contracts can be used simply to empower employers to outline an employee's duties and to regulate how the employee discharges them if realistic support is given to an employee (Ehlers, 2017).

\section{Fairness}

According to Sturman and Park (2016), employees with higher levels of satisfaction with their supervisor, and those with higher levels of job performance retain relatively positive perceptions of fairness.

\section{Good faith}

In one way or another, confidentiality is necessary to protect sensitive or personal information from disclosure to others (Munyoro, 2017).

Although these three variables have been discussed separately, the following section will explore the relationships amongst these variables, namely performance management, employment relationships and work engagement.

\section{The relationship between performance management and work engagement}

Human resource management systems can influence employees' opinions about job demands and resources, as well as their work engagement level (Bakker, 2017). Performance management is one of the systems that fall under the human resource management umbrella. Performance management can be used proactively to enhance work engagement to achieve the desired outcome. Unless and until employees in the public sector are satisfied with the performance management process, and they are truly engaged in their work, service in the public sector will not improve sufficiently. Noronha, Aquinas and Manezes (2018) provided empirical proof that for performance management to influence employees' job performance significantly, performance management first has to positively influence employees' attitudes towards work engagement. Evaluating, advancing and fostering work engagement are vital to an organisation's success (Knight et al., 2017).

In any institution, human resources depend on proper performance management processes and policies. However, when performance management is perceived as unfair and ineffectual, employees tend to be unproductive and negative towards the system (Makhubela, Botha, \& Swanepoel, 2016).

Without proper fair processes, rewards and motivation, performance management can actually provide opposite outcomes, such as absenteeism, poor performance and low levels of employee motivation and can create frustration in the organisation (Maina, 2015). It is a generally accepted fact that performance management is in a suitable position to enhance work engagement, which in turn leads to higher performance (Noronha et al., 2018). Performance management is often adopted to motivate employees. This can be realised by acknowledging expectations of a fair process and giving feedback on employees' progress towards meeting those expectations (Ahenkan, Tenakwah, \& Bawole, 2018). Higher levels of work engagement can lead to a more productive work environment with more committed and creative employees (Patrick \& Mukherjee, 2018).

\section{The relationship between performance management and employment relationships}

The relationship between managers and employees sets the general tone of the workplace. According to Ramulumisi (2014), performance management is viewed as a communication system between the supervisor and employees. In the case of 
South Africa, the system is set to provide feedback on employees' performance, reward outstanding performance and provide training to underperformers. Performance management activities include coaching, feedback, recognition, goal setting, identification of training needs, construction of development plans and career planning (Ricci, 2016). Performance management was introduced in the public sector to assist managers in evaluating and measuring employees' performance and productivity by, amongst others, defining roles, responsibilities and expectations (Public Service Commission, 2014). A review conducted by Arakal and Mampilly (2016) indicated that if employees perceive performance management as fair and accurate, they will accept it and employee involvement will increase. If there is uncertainty about the measuring tool, managers will be unable to evaluate employees' performance reliably (Legong, 2014). This can lead to poor employment relationships. If there are strong and healthy relationships in the organisation, one might expect employees to be happy and more productive (Rahman \& Taniya, 2017). Employees will improve their performance if they are aware of the organisational expectations, if they know how to do the work and if they know the standard of work that is required (Mbonambi, 2016). Supportive and pleasant employment working relationships will assist employees and managers to work together, thereby enhancing employees' performance (Ahmed, Ahmad, \& Jaaffar, 2017).

\section{The relationship between employee and immediate manager and work engagement}

A healthy employment relationship is essential to enriching work engagement. The concept of work engagement is deeply rooted in the job demands-resources theory that views engagement as a function of interaction between job demands and resources (Bakker, 2017). Job resources include feedback from clients, social care from co-workers, coaching, rewards and recognition from supervisors, as well as job control, participation and job security (Scanla \& Still, 2019). For this reason, support from one's supervisor and support and trusting relationships with co-workers are essential (Saratun, 2016). It is therefore clear that employees should be supportive of one another in their daily tasks by sharing knowledge and expertise as well as offering encouragement and showing concern (Gaire \& Fatta, 2016). Those co-workers and supervisors who support one another and show mutual respect will engender confidence and foster a psychological attitude of a secure and strong engagement with work (Ariani, 2015).

\section{Research design and methodology}

The research methodology presented here focuses on the research design, the methods and procedures for data collection and the measuring and analysis of data used in the study to address the research objectives.

\section{Research approach and research design}

The study employed a quantitative approach to collect primary data so that accurate and relevant information could be obtained, as the study was considered to be formal. The objective of a formal research design is to test the hypotheses or answer the research questions posed (Cooper \& Schindler, 2008). The study sought to address the following research questions:

- Are there any significant relationships amongst the three variables, namely performance management, work engagement and employment relationships?

- Is performance management a mediator for work engagement and employment relationships?

\section{Target population and sampling design}

There are 44 national departments within the South African public sector, and all 44 were approached to conduct the study there. However, eight departments, namely Arts and Culture; Planning, Monitoring and Evaluation; Science and Technology; Trade and Industry; Water and Sanitation; Rural Development and Land Reform; National School of Government and Basic Education gave permission to conduct the study with them. These departments had 16119 employees at the time of the study after the exclusion criteria had been considered. For the purpose of the study, only employees who had been employed for 5 years or more, who were permanently appointed and who were at job levels 1-12 within these eight national departments were targeted. With the inclusion criteria applied, the population for this study was 10660 employees. The reason for the inclusion of these employees was that they met the day-to-day challenges presented by the implementation of every policy in their respective departments and, most importantly, performance management. Further, employees who had been employed for 5 years or more were targeted because these employees had been exposed to performance management for this period and would thus be in a better position to respond to the questions posed in the survey. The study utilised non-probability purposive sampling. With the total population of $N=10660$, the researcher used the sample size of $n=400$ calculated according to the Raosoft@ calculator (Raosoft ${ }^{\circledR}$ Inc. USA, 2004) with a 5\% margin of error and 95\% confidenceinterval $(p \geq 0.5)$. Of the 400 distributed questionnaires, 372 were returned. However, 17 questionnaires had missing data and could not be used. The total number of usable responses was therefore 355 , which represented an $88.75 \%$ response rate.

\section{Measuring instrument}

The primary data for this study were collected using a structured questionnaire. The questionnaire for the current study was divided into four sections and comprised 74 closed and Likert-type scale response items. A combination of three existing questionnaires formed the basis of the measuring instrument. This study made use of three different sets of scales, namely four-, five- and seven-point Likert scales. A four-point Likert scale questionnaire designed by De Waal (2004) was used to measure performance management. A four-point Likert-scale questionnaire designed by Schaufeli, Bakker and Salanova (2006) was used to measure the levels of work engagement. A seven-point Likert-scale questionnaire designed 
by Ehlers (2016) was used to measure employment relationships.

Prior to data collection, a pilot study was carried out with 10 employees to determine whether the questionnaire questions were clear and understandable to the participants. These 10 participants were selected through convenience sampling.

\section{Data collection}

After the pilot testing, arrangements to deliver structured questionnaires were made with unit managers at the national departments in the public sector in South Africa. Four hundred questionnaires were personally distributed and collected by the researcher and two fieldworkers.

\section{Data analysis}

The captured data were coded and subsequently checked for possible errors of completion resulting in the elimination of 17 questionnaires. The Statistical Package for the Social Sciences (SPSS) was used to calculate descriptive and inferential statistics. The Pearson correlation coefficient was employed to determine whether relationships existed amongst the variables, namely performance management, employment relationships , work engagement and multiple regression analysis was used to measure the extent to which performance management mediated the relationship between work engagement and employment relationships.

\section{Validity and reliability of the measuring instrument}

To ensure the validity of the questionnaire, the research instrument was presented to study supervisors and public sector management. Professionals in the field of statistics scrutinised the questionnaire to ensure that it would answer the research questions. This was done to determine whether this measurement tool would be suitable to achieve the research objectives. To assess the reliability of the questionnaire, Cronbach's alpha coefficients were calculated for the various subscales of the questionnaire, namely performance management, employment relationships and work engagement.

The Cronbach's alpha values for the 12 sub-scales are reported in Table 1. A high Cronbach's alpha value indicates a strong correlation between items on a scale (Chrispin, Scotton, Rogers, Lloyd, \& Ridley, 1997). Bryman and Bell (2007) stated that Cronbach's alpha values of 0.70 and above are used as a rule of thumb to denote a high level of internal reliability. All 12 sub-scales were found to demonstrate acceptable levels of reliability, ranging from 0.73 to 0.94 .

\section{Ethical considerations}

Ethical clearance (reference no: FCRE2018/FR/05/008-MS) for this study was obtained from the Faculty Committee for
TABLE 1: Summary of Cronbach's alpha values for the 12 sub-scales.

\begin{tabular}{lcc}
\hline Variable & Cronbach's alpha & $N$ of items \\
\hline Work engagement & & \\
Vigour & 0.789 & 6 \\
Dedication & 0.848 & 5 \\
Absorption & 0.811 & 6 \\
Employment relationships & & \\
Compliance & 0.873 & 4 \\
Fairness & 0.827 & 3 \\
Good faith & 0.814 & 3 \\
Trust & 0.944 & 10 \\
Performance management & & \\
Understanding of performance management & 0.828 & 4 \\
Attitude towards performance management & 0.786 & 6 \\
Performance management alignment & 0.872 & 9 \\
Performance management culture & 0.803 & 5 \\
Performance management focus & 0.726 & 5 \\
\hline
\end{tabular}

Research Ethics at the Tshwane University of Technology. In this study, ethics and the protection of the dignity of all stakeholders were ensured.

\section{Results}

\section{Correlations amongst work engagement, employment relationships and performance management totals}

One-tailed (see Table 2) and two-tailed (see Table 3) tests were performed to determine whether differences were evident between performance management, work engagement and employment relationships. Table 2 presents the Pearson's $R$ statistic and a sig. (onetailed) value for the correlation amongst performance management, work engagement and employment relationship totals.

It can be seen in Table 2 that the correlation between the performance management and employment relationships totals (sig. [one tailed] $=0.0001$ ) was 0.503. Based on Cohen's (1988) guideline, this may be classified as a strong correlation. This shows that, when effective performance management processes are in place, employment relationships are likely to improve significantly. A moderate correlation of 0.423 was found between the performance management and work engagement totals, and the correlation between the employment relationships and work engagement totals was 0.387 , both with the significance level set at 0.01 . It can be concluded from the correlation analysis results that a moderate correlation existed between performance management and work engagement and a strong correlation existed between performance management and employment relationships.

A two-tailed test was done, with Table 3 presenting the Pearson's $R$ statistic and sig. (two-tailed) value for the levels of correlation amongst the performance management, work engagement and employment relationship totals.

As depicted in Table 3, the correlation between the performance management and work engagement totals was 0.423 , and the correlation between the employment 
TABLE 2: Pearson's $R$ statistic and significant (one-tailed) value.

\begin{tabular}{lccc}
\hline Relationship between variables & $\begin{array}{c}\text { Performance } \\
\text { management } \\
\text { total }\end{array}$ & $\begin{array}{c}\text { Work } \\
\text { engagement } \\
\text { total }\end{array}$ & $\begin{array}{c}\text { Employment } \\
\text { relationships } \\
\text { total }\end{array}$ \\
\hline Pearson's correlation & & & \\
Performance management total & 1.000 & $0.423^{*}$ & $0.503^{*}$ \\
Work engagement total & 0.423 & 1.000 & $0.387^{*}$ \\
Employment relationships total & 0.503 & 0.387 & 1.000 \\
Sig. (one tailed) & & & \\
Performance management total & - & 0.000 & 0.000 \\
Work engagement total & 0.000 & - & 0.000 \\
Employment relationships total & 0.000 & 0.000 & 0.000 \\
N & & & \\
Performance management total & 352 & 352 & 352 \\
Work engagement total & 352 & 352 & 352 \\
Employment relationships total & 352 & 352 & 352 \\
\hline
\end{tabular}

Sig., significant.

*, Correlation is significant at the 0.01 level (one tailed).

TABLE 3: Pearson's $R$ statistic and significant (two-tailed) value.

\begin{tabular}{lccc}
\hline Relationship between variables & $\begin{array}{c}\text { Work } \\
\text { engagement } \\
\text { total }\end{array}$ & $\begin{array}{c}\text { Performance } \\
\text { management } \\
\text { total }\end{array}$ & $\begin{array}{c}\text { Employment } \\
\text { relationships } \\
\text { total }\end{array}$ \\
\hline Work engagement total & 1 & $0.423^{* *}$ & $0.387^{* *}$ \\
Pearson's correlation & - & 0.000 & 0.000 \\
Sig. (two tailed) & 353 & 353 & 352 \\
$N$ & & & \\
Performance management total & $0.423^{* *}$ & 1 & $0.503^{* *}$ \\
Pearson's correlation & 0.000 & - & 0.000 \\
Sig. (two tailed) & 353 & 355 & 354 \\
$N$ & & & \\
Employment relationships total & $0.387^{* *}$ & $0.503^{* *}$ & 1 \\
Pearson's correlation & 0.000 & 0.000 & - \\
Sig. (two tailed) & 352 & 354 & 354 \\
$N$ & & &
\end{tabular}

Sig., significant.

**, Correlation is significant at the 0.01 level (two tailed).

relationships and work engagement totals was 0.387, both with the significance level set at 0.01 . According to Cohen (1988), these may be classified as moderate correlations. A significant positive correlation was found between the employment relationships and performance management totals (sig. [two tailed] $=0.0001$ ), with a correlation of 0.503 , indicating a large correlation. This shows that when performance management processes are perceived to be effective, employment relationships are likely to improve significantly. It can thus be inferred from the correlation analysis results that moderate levels of correlation existed between performance management and work engagement and a strong correlation existed between performance management and employment relationships.

\section{Mediation of relationships amongst work engagement, employment relationships and performance management}

According to Baron and Kenny (1986), mediation is a hypothesised causal chain in which one variable affects a second variable that, in turn, affects a third variable. In other words, a mediator is a variable that mediates the relationship between the dependent and independent variables. In this study, a multiple regression analysis was used to determine whether performance management was a mediator between work engagement and employment relationships. The results of this multiple regression analysis were tested. Tables $4-6$, as well as Figures 1 and 2, show the level to which the variables were related to each other and the level to which the mediator variable mediated the relationship between the independent variable and the dependent variable. According to Baron and Kenny (1986), there are four steps in testing for mediation.

An explanation of the four steps in mediation is presented in the following subsections.

\section{Step 1}

This step established the relationship between work engagement $(X)$ and performance management $(Y)$, which are the variables that illustrate path $\mathrm{C}$ of the mediation model. In Table 4, the regression of work engagement (i.e. independent/predictor variable) on performance management (i.e. dependent/outcome variable) is shown through a coefficient of $\beta=0.1869, p=0.000$, which is evidence of a significant regression. Accordingly, it can be concluded that effective performance management fosters greater levels of engagement. However, this work engagement can be strengthened only by taking advantage of designing and implementing performance management that will boost employees' work engagement levels. Therefore, it is suggested that management in the public sector in South Africa takes necessary steps to design effective performance management in order to foster work engagement in the organisations.

\section{Step 2}

Table 6, represented by path A of the mediation model as indicated in Figure 2, shows that the independent variable, namely work engagement $(X)$, was correlated to the mediator, namely performance management $(\mathrm{M})$. This step essentially involves treating the mediator as if it were an outcome variable and represents the path above. In the regression of work engagement on the mediator, work engagement was also significant, with $\beta=0.2294, p=0.000$. This result proves that positive employment relationships will foster greater levels of engagement.

\section{Step 3}

Table 6, represented by path B in Figure 2, indicates the relationship between employment relationships $(\mathrm{M})$ and performance management $(\mathrm{Y})$. In this case, the regression of the employment relationships (mediator) on performance management (independent variable) was $\beta=0.2978, p=0.000$, controlling for work engagement. This significant regression showed that performance management made a positive contribution to employment relationships. Practically, this influence can be enhanced only if the performance management process is perceived to be fair, unbiased and transparent.

\section{Step 4}

As seen in Figure 2, path C shows that employment relationships (M) mediated the relationship between work engagement $(X)$ 
TABLE 4: Mediation process.

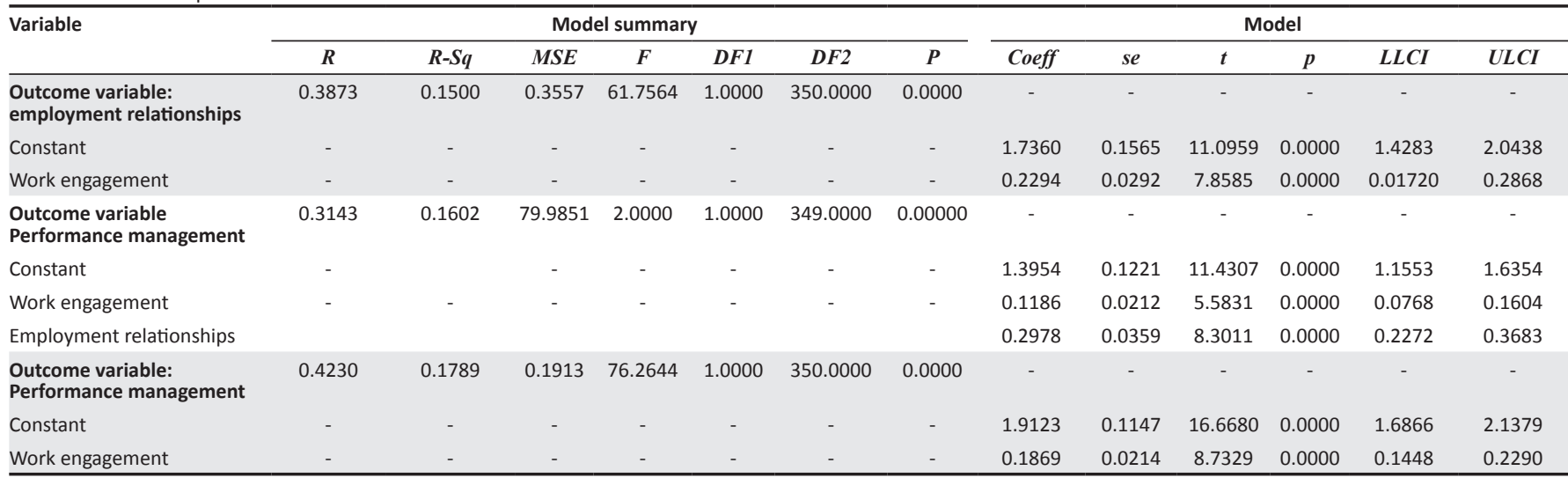

MSE, mean square errors; ULCI, upper limit confidence intervals; LLCI, lower limit confidence intervals; DF, degree of freedom; SE, standard error.

TABLE 5: Mediation total and direct and indirect effects of work engagement $(\mathrm{X})$ on performance management $(\mathrm{Y})$

\begin{tabular}{|c|c|c|c|c|c|c|c|c|c|c|c|}
\hline Variable & Effect & $S E$ & $T$ & $p$ & $L L C I$ & $U L C I$ & C_ps & $C_{-} c s$ & BootSE & BootLLCI & BootULCI \\
\hline \multicolumn{12}{|c|}{ Total effect of work engagement on performance management } \\
\hline- & 0.1869 & 0.0214 & 8.7329 & 0.0000 & 0.1448 & 0.2290 & 0.3878 & 0.4230 & - & - & - \\
\hline \multicolumn{12}{|c|}{ Direct effects on work engagement on performance management } \\
\hline- & 0.1186 & 0.0212 & 5.5831 & 0.0000 & 0.0768 & 0.1604 & 0.2461 & 0.2684 & - & - & - \\
\hline \multicolumn{12}{|c|}{ Indirect effect of work engagement on performance management } \\
\hline Employment relationships & 0.0683 & - & - & - & - & - & - & - & 0.0142 & 0.0420 & 0.0976 \\
\hline
\end{tabular}

$\mathrm{SE}$, standard error; LLCI, lower limit confidence intervals; ULCI, upper limit confidence intervals; C_ps, Completely standardised effect; C_cs, Partially standardised effect.

TABLE 6: Bootstrap results for regression model parameters.

\begin{tabular}{lccccc}
\hline Variable & Coeff & BootMean & BootSE & BootLLCI & BootULCI \\
\hline Outcome variable: employment relationships & & & \\
Constant & 1.7360 & 1.7361 & 0.1527 & 1.4486 & 2.0506 \\
Work engagement & 0.2294 & 0.2294 & 0.0284 & 0.1705 & 0.2836 \\
Outcome variable: performance management & & & \\
Constant & 1.3954 & 1.3930 & 0.1398 & 1.1272 & 1.6780 \\
Work engagement & 0.1186 & 0.1184 & 0.0224 & 0.0746 & 0.1619 \\
Employment relationships & 0.2978 & 0.2990 & 0.0418 & 0.2152 & 0.3813 \\
\hline
\end{tabular}

Coeff., coefficient; $\mathrm{LLCl}$, lower limit confidence intervals; ULCI, upper limit confidence intervals; SE, standard error.

and performance management $(\mathrm{Y})$. If the effect of $\mathrm{X}$ on $\mathrm{Y}$, controlling for $\mathrm{M}$, were zero, this would show complete mediation. This analysis revealed that, controlling for the mediator (employment relationships), work engagement was a significant predictor of performance management $(\beta=$ $0.1186, p=0.000)$, which implied partial mediation. Preacher and Hayes (2004) posited that, where the effect of variable $X$ on variable $Y$ is reduced or decreased after the inclusion of the mediator variable, the effect is said to have been partially mediated. It should be noted that the significant regression of the independent variable (work engagement) on the dependent variable (performance management) was $\beta=0.1869$, but this was reduced to $\beta=0.1186$ when the mediator (work engagement) was included. It is also stated that satisfying all four conditions can provide evidence for complete mediation, whereas satisfying only the first three conditions indicates partial mediation.

The mediation total and the direct and the indirect effects of work engagement $(X)$ on performance management $(Y)$ are illustrated in Table 5 .
The bootstrap results for the regression model parameters are illustrated in Table 6.

Figure 1 elaborates on the relationship between work engagement $(\mathrm{X})$ and performance management $(\mathrm{Y})$.

Figure 2 illustrates the effect that employment relationships (M) had on the relationship between work engagement $(X)$ and performance management $(\mathrm{Y})$.

These findings provide sufficient proof to suggest that performance management did play a mediatory role for employment relationships and work engagement in the public sector, as illustrated in Tables 4-6. Therefore, it is essential for management in the public sector to implement appropriate steps to develop effective performance management to foster strong employment relationships and high levels of work engagement.

\section{Discussion}

Correlation coefficients in this study were used to describe whether there were significant relationships between performance management, employment relationships and work engagement in the public sector. Tables 2 and 3 showed that performance management had a positive influence on employment relationships and work engagement levels. Conversely, the relationship between work engagement and employment relationships was fairly weak (0.387) compared to the relationship between performance management and work engagement (0.423) and between performance management and employment relationships (0.503). The study showed that performance management had a substantial 


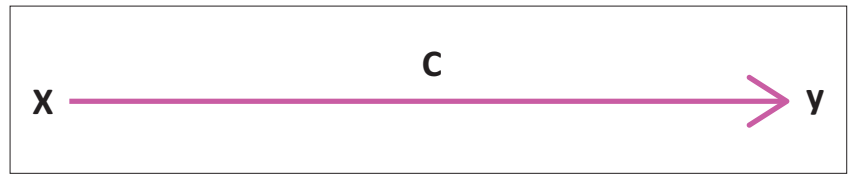

Source: Baron, R.M., \& Kenny, D.A. (1986). The moderator-mediator variable distinction in social psychological research: Conceptual, strategic, and statistical considerations. Journal of Personality and Social Psychology, 51(6), 1173-1182. https://doi.org/10.1037/00223514.51.6.1173

FIGURE 1: Illustration of a direct effect: $X$ directly affects $Y$

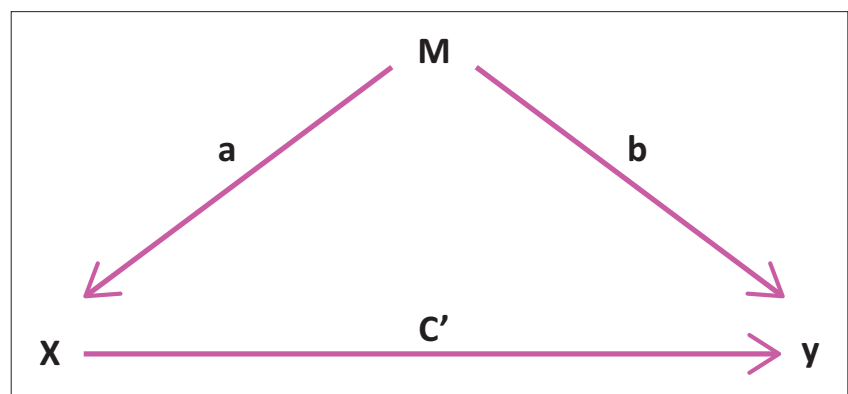

Source: Baron, R.M., \& Kenny, D.A. (1986). The moderator-mediator variable distinction in social psychological research: Conceptual, strategic, and statistical considerations. Journal of Personality and Social Psychology, 51(6), 1173-1182. https://doi.org/10.1037/00223514.51.6.1173

FIGURE 2: Illustration of a mediation design: $X$ affects $Y$ indirectly through $M$.

influence on the employment relationship level while it had a moderate influence on the work engagement level. This implies that stronger or weaker scores in work engagement do not necessarily have a huge impact on performance management. Empirical evidence shows that performance management and work engagement are classified under human resource practices. In view of this, Bakker (2017) recommended the introduction of key performance management activities that have a positive influence on work engagement, such as setting performance and development goals, providing ongoing feedback and recognition, monitoring employees' development, conducting appraisals and creating a climate of trust and empowerment. Noronha et al. (2018) stated that for a performance management to have an impact on how employees perform their tasks, performance management has to address work engagement. Noronha et al. (2018) further indicated that performance management has its own way of ensuring work engagement, which in turn leads to higher performance.

Moreover, this implies that employment relationships are associated positively with performance management. In practical terms, when performance management is used efficiently by supervisors, employment relationships are likely to improve significantly. In this regard, Brhane and Zewdie (2018) recommended that organisations be required to build strong relationships, put in place mechanisms to motivate employees and provide opportunities to resolve conflicts that arise in the workplace. It is suggested that employees need to perceive performance management as fair if good employment relationships are to be maintained. This can significantly minimise levels of bias. When performance management is perceived as accurate, fair and unbiased by employees, appraisal satisfaction and improved employment relationships will follow (Taneja, Srivastava, \&
Ravichandran, 2015). In fact, the effective performance management in an organisation will help employees to recognise their own strengths and weaknesses, thereby advancing their knowledge, skills and attitudes in relation to their expectations and abilities (Singh \& Twalo, 2015). Finally, Ahmed et al. (2017) concluded that a favourable working environment will ensure healthy working relationships between employees and managers.

Similarly, the results showed that there was a positive correlation between work engagement and employment relationships. This implies that where employees have better employment relationships, their work engagement will be higher. It is evident from the literature that work engagement is a positive, fulfilling work-related state of mind that is characterised by vigour, dedication and absorption (Bakker, 2017). Moreover, it follows that employees who are unhappy about their employment relationships will have a negative state of mind. A detailed literature review of previous studies has shown that engagement is a proximal concept that influences employees' performance and reveals how they respond to the resources they receive (Gupta, Acharya, \& Gupta, 2015).

The results of this study indicated that performance management was a mediator between work engagement and employment relationships. To date, no other study has reported on the mediating role of performance management between employment relationships and work engagement. It is suggested that management in the public sector should take the necessary steps to address performance management-related issues to foster sound employment relationships and work engagement, which will ensure better employee performance.

\section{Practical implications}

From a theoretical point of view, the study is expected to make a valuable contribution to an understanding of performance management, employment relationships and work engagement as well as adding to the literature that focuses on performance management, employment relationships and work engagement in the South African public sector context. In any institution, performance management, employment relationships and work engagement rely primarily on competent practitioners and fair human resource practices. One of the most important factors when applying performance management in the public sector is to understand the role and objectives of performance management and work engagement. Unless and until employees in the public sector are satisfied with the performance management process, and a strong employment relationship and work engagement are in place, the public sector will be unable to progress sufficiently or achieve optimal success in service delivery. This study endeavoured to address this issue. From a practical perspective, the study makes some valuable contributions. Based on the results of the study, public sector management 
should be encouraged to make decisions that can enhance the efficient and fair process of managing employee performance. The study may urge management to pay specific attention to those aspects that are not conducive to performance management, as indicated by participants.

\section{Limitations and recommendations}

Given the exploratory nature of the study, the following limitations were encountered:

As this study had a limited number of participants and only included those permanent employees who had been employed for 5 years or more in the public sector, more research is needed in a similar setting to give credence to the current findings. Although all 44 national departments in SA were approached, data were collected from the eight national departments who gave permission for the study to be conducted at their departments. It may be possible to generalise the results to other public sector departments, but the results might not be applicable to other institutions in the private sector and private government entities.

The following recommendations are put forward based on the study results:

- Managers should provide adequate and regular feedback to employees. Reliable information and feedback should focus on both employees' weaknesses and strengths. This is essential if managers are to address the underperformance of employees specifically and not to ignore problems.

- Feedback on underperformance should be provided with tact and insight to minimise rejection and negativity on the part of employees.

- Management should ensure that the mechanisms and procedures of performance management are perceived as fair, consistent, relevant, transparent and unbiased and that performance management processes be clearly communicated to employees. Otherwise, if the process is perceived as ineffectual, employees may refuse to cooperate with managers, and national departments may lose their employees' loyalty, good faith and trust.

- In future, similar studies should be conducted at other government departments internationally, as well as in other industries, to compare obtained results.

- A qualitative study should be conducted to provide more information on performance management, employment relationships and work engagement in the public sector in South Africa.

\section{Conclusion}

The main aim of the study on which this article is based was to pose and answer questions on whether performance management could be a mediator for work engagement and employment relationships in the public sector in South Africa. A comprehensive literature review revealed numerous research studies on performance management, employment relationships and work engagement and interesting insights were gained. This study showed moderate levels of correlation between performance management and work engagement and strong levels of correlation between performance management and employment relationships. The results of this study also indicated that performance management was indeed a mediator between work engagement and employment relationships. The findings of this study should motivate management of the public sector to pay attention to the implementation of performance management as the driving instrument for changing the behaviour and working methods of employees to achieve certain outcomes.

\section{Acknowledgements Competing interests}

The authors declare that they have no financial or personal relationship(s) that may have inappropriately influenced them in writing this article.

\section{Authors' contributions}

G.M. conducted the research and C.P.J.H. and C.M.S. supervised the research and co-wrote the article.

\section{Funding information}

This research received no specific grant from any funding agency in the public, commercial, or not-for-profit sectors.

\section{Data availability}

Data availability/sharing is not applicable in this research.

\section{Disclaimer}

The views expressed in the submitted article are the author's own and not an official position of the institution or funder.

\section{References}

Ahenkan, A., Tenakwah, E.S., \& Bawole, J.N. (2018). Performance management implementation challenges in Ghana's local government system: Evidence from the Sefwi Wiawso Municipal Assembly. International Journal of Productivity and Performance Management, 67(3), 519-535. https://doi.org/10.1108/ IJPPM-06-2016-0124

Ahmed, S., Ahmad, F.B., \& Jaaffar, A.R. (2017). Employee engagement on employee relation supervisor and employee performance relationship in developing economy: Critical analysis with PLS-SEM. Saudi Journal of Business and Management Studies, 2(4), 389-398. https://doi.org/10.21276/sjbms

Al-Khozondar, N.O. (2015). Employee relationship management and its effect on employees' performance at telecommunication and banking sectors. Unpublished master's dissertation. Gaza: The Islamic University.

Arakal, T., \& Mampilly, S.R. (2016). An empirical attestation of the impact of performance management system on employee involvement moderated by employee acceptance of performance management system. Journal of Business and Management, 18(1), 25-32.

Ariani, D.W. (2015). Relationship with supervisor and co-workers, psychological condition and employee engagement in the workplace. Journal of Business and Management, 4(3), 34-45. https://doi.org/10.12735/jbm.v4i3p34

Bakker, A.B. (2017). Strategic and proactive approaches to work engagement. Organisational Dynamics, 46(2), 67-75. https://doi.org/10.1016/j.orgdyn.2017. 04.002

Bakker, A.B., \& Albrecht, S. (2018). Work engagement: Current trends. Career Development International, 23(1), 4-11. https://doi.org/10.1108/CDI-11-20170207

Baron, R.M., \& Kenny, D.A. (1986). The moderator-mediator variable distinction in social psychological research: Conceptual, strategic, and statistical considerations. Journal of Personality and Social Psychology, 51(6), 1173-1182. https://doi. org/10.1037/0022-3514.51.6.1173 
Boikanyo, D.H., \& Heyns, M.M. (2019). The effect of work engagement on total quality management practices in a petrochemical organisation. South African Journal of
Economic and Management Sciences, 22(1), 2334. https://doi.org/10.4102/ sajems.v22i1.2334

Brhane, H., \& Zewdie, S. (2018). A literature review on the effects of employee relation on improving employee performance. International Journal in Management and Social Science, 6(4), 66-76.

Bryman, A., \& Bell, E. (2007). Business research methods. 2nd ed. New York, NY: Oxford University Press.

Chrispin, P.S., Scotton, H., Rogers, J., Lloyd, D., \& Ridley, S.A. (1997). Short form 36 in the intensive care unit: Assessment of accountability, reliability and validity of the questionnaire. Anaesthesia, 52(1), 15-23. https://doi.org/10.1111/j.1365-2044. 1997.015-az014.x

Cohen, J. (1988). Statistical power analysis for the behavioural sciences. Orlando, FL: Academic.

Cooper, D.R., \& Schindler, P.S. (2008). Business research methods. 10th ed. New York, NY: McGraw-Hill.

De Oliveira, L.B., \& Rocha, J.D. (2017). Work engagement: Individual and situational antecedents and its relationship with turnover intention. Business Management, 19(65), 415-437. https://doi.org/10.7819/rbgn.v19i64.3373

De Spiegelaere, S., Van Gyes, G., \& Van Hootegem, G. (2016). Not all autonomy is the same: Different dimensions of job autonomy and their relation to work engagement and innovative work behaviour. Human Factors and Ergonomics in Manufacturing and Service Industries, 26(4), 515-527. https://doi.org/10.1002/ hanufacturing 20666

De Waal, A.A. (2004). Stimulating performance-driven behaviour to obtain better results. International Journal of Productivity and Performance Management, 53(4), 301-316. https://doi.org/10.1108/17410400410533890

Ehlers, L.I. (2016). Measuring primary employment relationship satisfaction in South African supervisory relationships. Journal of Contemporary Management, 13, 745-766.

Ehlers, L.I. (2017). Conceptualising primary labour relationship quality. South African Journal of Economic and Management Sciences, 20(1), 1-11. https://doi.org/ 10.4102/sajems.v20i1.1573

Gaire, A.K.S., \& Fatta, B.K.C. (2016). Co-workers' impact on attitudinal behaviour of the faculty members of educational institutions of Nepal. Journal of Advanced Academic Research, 3(1), 1-11. https://doi.org/10.3126/jaar.v3i1.16613

Gallup. (2017). State of the global workplace. New York, NY: Gallup Press.

Georgalis, J., Samaratunge, R., \& Kimberley, N. (2015). Change process characteristics and resistance to organisational change: The role of employee perceptions of justice. Australian Journal of Management, 40(1), 89-113. https://doi.org/ $10.1177 / 0312896214526212$

Gulch, D.A. (2016). The impact of performance appraisal on productivity: Case of Hamaressa Edible Oil S.C. Unpublished master's dissertation. New Delhi: Ignou People University.

Gupta, M., Acharya, A., \& Gupta, R. (2015). Impact of employment on performance in Indian higher education system. Review of European Studies, 7(3), 192-201. https://doi.org/10.5539/res.v7n3p192

Hassan, S., \& Hatmaker, D.M. (2016). Leadership and performance of public employees: Effects of the quality and characteristics of manager-employee relationships. Journal of Public Administration Research, 25(4), 1127-1155. https://doi.org/10.1093/jopart/muu002

Isaacs, J.D. (2016). The impact of transformational leadership on performance management: A South African local government case study. Unpublished master's thesis. Cape Town: Stellenbosch University.

Kahn, W.A. (1990). Psychological conditions of personal engagement and disengagement at work. Academy of Management Journal, 33(4), 692-724. https://doi.org/10.5465/256287

Kim, W., Han, S.J., \& Park, J. (2019). Is the role of work engagement essential to employee performance or 'nice to have'? Sustainability, 11(4), 1-16. https://doi. org/10.3390/su11041050

Knight, C., Patterson, M., \& Dawson, J. (2017). Building work engagement: A systematic review and meta-analysis investigating the effectiveness of work engagement interventions. Journal of Organisational Behaviour, 38(6), 792-812. https://doi. interventions. Journal
$\mathrm{org} / 10.1002 /$ job.2167

Kotola, H. (2016). Managing underperformance. Unpublished master's thesis. Helsinki: Arcada University of Applied Sciences.

Legong, F.E. (2014). Performance management as a tool to improve performance outcomes at a water trading entity. Unpublished master's dissertation. Pretoria: Tshwane University of Technology.

Mafini, C., \& Pooe, D.R.I. (2014). A framework for linking process factors to organisational performance in a government department. International Business and Economics Research Journal, 13(5), 981-996. https://doi.org/10.19030/iber. v13i5.8766

Maimela, E.M., \& Samuel, M.O. (2016). Perception of performance management system by academic staff in an open distance learning higher education environment. SA Journal of Human Resource Management, 14(1), 1-11. https:// doi.org/10.4102/sajhrm.v14i1.784

Maina, J.M. (2015). Effect of performance management system on employee performance: A study of food and agriculture organisation. Unpublished master's dissertation. United States International University Africa.

Makamu, N.I. (2016). Assessment of performance management and development system in selected South African national government departments. PhD thesis. Potchefstroom: North-West University.
Makhubela, M., Botha, P.A., \& Swanepoel, S. (2016). Employees' perceptions of the effectiveness and fairness of performance management in a South African public sector institution. SA Journal of Human Resource Management, 14(1), 1-11. https://doi.org/10.4102/sajhrm.v14i1.728

Matjila, T.S. (2015). Employee perceptions of the performance management system at the South African post office in Pretoria. Unpublished master's dissertation. Pretoria: Tshwane University of Technology.

Matthews, M., Carsten, M.K., Ayers, D.J., \& Menachemi, N. (2017). Determinants of turnover among low wage earners in long term care: The role of manageremployee relationships. Geriatric Nursing, 39(4), 407-413. https://doi.org/ 10.1016/j.gerinurse.2017.12.004

Mbonambi, S.S. (2016). An evaluation of a performance management system in a freight rail organisation. Unpublished master's dissertation. Pretoria: University of South Africa.

Mulwa, M.N., \& Weru, J.M. (2017). The influence of performance management system on employee performance in commercial banks in Kitui Town, Kitui County, System on employe performance in commercial banks in Kitui Town, Kitui
Kenya. International Journal of Humanities and Social Science, 7(6), 44-55.

Mundia, L., Mahalle, S., Matzin, R., Zakari, G.A.A., Abdullah, N.Z.A., \& Latif, S.N.A. (2017). Prediction of employer-employee relationships from socio demographic variables and social values in Brunei public and private sector workers. Psychology
Research and Behaviour Management, 10, 257-269. https://doi.org/10.2147/ PRBM.S136479

Munyoro, I. (2017). Issues of confidentiality and public interest: A case study from a library perspective. South African Journal of Information Studies, 35(3), 1-17. https://doi.org/10.25159/0027-2639/2413

Munzhedzi, P.H. (2017). A reflection on the relationship between performance management and training in the South African public service. SA Journal of Human Resource Management, 15, a864. https://doi.org/10.4102/sajhrm. v15i0.864

National Treasury. (2016). National budget review 2016. Pretoria: Government Printer.

Noronha, S.F., Aquinas, P.G., \& Manezes, A.D. (2018). Is job performance better attributable to performance management system through work engagement. Indian Journal of Commerce and Management Studies, 9(1), 1-6. https://doi. org/10.18843/ijcms/v9i1/01

Nxumalo, N., Goudge, J., Gilson, L., \& Eyles, J. (2018). Performance management in times of change: Experiences of implementing a performance assessment system in a district in South Africa. International Journal for Equity in Health, 17, 141 https://doi.org/10.1186/s12939-018-0857-2

Okwir, S., Nudurupati, S.S., Ginieis, M., \& Angelis, J. (2018). Performance measurement and management systems: A perspective from complexity theory. International Journal of Management Reviews, 20(3), 731-754. https://doi.org/10.1111/ ijmr.12184

Osborne, S., \& Hammoud, M.S. (2017). Effective employee engagement in the workplace. International Journal of Applied Management and Technology, 16(1) 50-67. https://doi.org/10.5590/IJAMT.2017.16.1.04

Pandita, S., \& Singhal, R. (2017). The influence of employee engagement on the worklife balance of employees in the IT sector. The IUP Journal of Organisational Behaviour, 16(1), 38-57.

Patrick, H.A., \& Mukherjee, U. (2018). Work engagement: A cross sectional study of employees in the healthcare sector. The Journal - Contemporary Management Research, 12(1), 60-79.

Preacher, K.J., \& Hayes, A. (2004). SPSS and SAS procedures for estimating indirect effects in simple mediation models. Behaviour Research Methods, Instruments and Computers, 36(4), 717-731. https://doi.org/10.3758/BF03206553

Rachman, S.A., \& Suhartini, S. (2019). The role of work engagement in moderating the impact of job characteristics, perceived organizational support, and self-efficacy on job satisfaction. Integrated Journal of Business and Economics, 3(1), 15-31. https://doi.org/10.33019/ijbe.v3i1.112

Rahman, S., \& Taniya, R.K. (2017). Effect of employee relationship management (ERM) on employee performance: A study on private commercial banks in Bangladesh. Human Resource Management Research, 7(2), 90-96.

Ramulumisi, T.V. (2014). The relationship between the performance management system and employee relations at the Department of Rural Development and Land Reform. Unpublished master's dissertation. Pretoria: Tshwane University of Technology.

Rana, S., Pant, D., \& Chopra, P. (2019). Work engagement and individual work performance: Research findings and an agenda for employee relationships. Journal of Emerging Technologies and Innovative Research, 6(5), 17-32.

Raosoft ${ }^{\oplus}$ Inc.USA. (2004). Raosoft ${ }^{\circledR}$ sample size calculator. Retrieved from http:// www.raosoft.com/samplesize.html

Ricci, L.M. (2016). The impact of performance management system characteristics on perceived effectiveness of the system and engagement. Unpublished master's dissertation. San José, CA: San José State University.

Rotich, R.K., Cheruiyot, T.K., \& Korir, M.K. (2016). Effects of demographics on the relationship between optimism and work engagement among employees of state agencies in Kenya. Journal of Resources Development and Management, 18, 32-42.

Sachane, M., Bezuidenhout, A., \& Botha, C. (2018). Factors that influence employee perceptions about performance management at statistics South Africa. SA Journa of Human Resource Management, 16(0), 1-8. https://doi.org/10.4102/sajhrm. v16i0.986

Samwel, J.O. (2018). Effect of employee relations on employee performance and organizational performance: Study of small organizations in Tanzania. International Research Journal, 18(8), 30-39. https://doi.org/10.5296/ijhrs.v8i3.13415

Saratun, M. (2016). Performance management to enhance employee engagement for corporate sustainability. Asia-Pacific Journal of Business Administration, 8(1), 84-102. https://doi.org/10.1108/APJBA-07-2015-0064 
Scanla, J.N., \& Still, M. (2019). Relationships between burnout, turnover intention, job satisfaction, job demands and job resources for mental health personnel in an
Australian mental health service. BMC Health Services Research, 19, 62. https:// doi.org/10.1186/s12913-018-3841-z

Schaufeli, W.B., Bakker, A.B., \& Salanova, M. (2006). The measurement of work engagement with a short questionnaire: A cross-national study. Educational and Psychological Measurement, 66(4), 701-716. https://doi.org/10.1177/ 0013164405282471

Schaufeli, W.B., Salanova, M., Gonzalez-Roma, V., \& Bakker, A.B. (2002). The measurement of engagement and burnout: A two simple confirmatory factor analytic approach. Journal of Happiness Studies, 3, 71-92. https://doi. org/10.1023/A:1015630930326

Singh, P., \& Twalo, T. (2015). Effects of poorly implemented performance management systems on the job behaviour and performance of employees. International Business and Economics Research Journal, 14(1), 79-94. https://doi.org/10.19030/ iber.v14i1.9034

South Africa, Public Service Commission. (2014). Report on constitutional and legislative mandate of the public service commission. Pretoria: Government Printer.

Sturman, M., \& Park, S. (2016). The changing relationship between supervisors and subordinates: How managing this relationship evolves over time. Cornell Hospitality Report, 16(13), 1-10.
Subramanian, K.R. (2017). Employer employee relationship and impact on organisation structure and strategy. International Journal of Innovative Trends in Engineering, 43(27), 39-45.

Taneja, S., Srivastava, R., \& Ravichandran, N. (2015). Consequences of performance appraisal justice perception: A study of Indian banks. Journal of Organisational Behaviour, 14(3), 33-57.

Tweedie, D., Wild, D., Rhodes, C., \& Martinov-Bennie, N. (2019). How does performance management affect workers? Beyond human resource management and its critique. International Journal of Management Reviews, 21, 76-96. https:// doi.org/10.1111/ijmr.12177

Van Wingerden, J., Bakker, A.B., \& Derks, D. (2016). A test of a job demands-resources intervention. Journal of Managerial Psychology, 31(3), 686-701. https://doi. org/10.1108/JMP-03-2014-0086

West, D., \& Blackman, D. (2015). Performance management in the public sector. Australian Journal of Public Administration, 74(1), 73-81. https://doi. org/10.1111/1467-8500.12130

Woyessa, Y.E. (2015). The effectiveness of performance management systems at the Central University of Technology, Free State. Unpublished master's dissertation. Bloemfontein: University of the Free State.

Xesha, D., Iwu, C.G., Slabbert, A., \& Nduna, J. (2014). The impact of employeremployee relationships on business growth. Journal of Economics, 5(3):313-324. https://doi.org/10.1080/09765239.2014.11885007 